\title{
Physical Shift
}

National Cancer Institute

\section{Source}

National Cancer Institute. Physical Shift. NCI Thesaurus. Code C73943.

A physical movement from one place to another. 